\title{
Evaluation of antibacterial and toxicological activities of essential oil of Ocimum gratissimum $L$. and its major constituent Eugenol
}

Julio Cesar Silva ( $\square$ juliocesar.bioprospeccao@gmail.com )

Universidade Regional do Cariri https://orcid.org/0000-0003-3602-3776

Raimundo Luiz Silva Pereira

Universidade Regional do Cariri

Thiago Sampaio de Freitas

Universidade Regional do Cariri

Janaína Esmeraldo Rocha

Regional University of Cariri: Universidade Regional do Cariri

Nair Silva Macedo

Regional University of Cariri: Universidade Regional do Cariri

Carla de Fatima Alves Nonato

Universidade Regional do Cariri

Marina Leite Linhares

Universidade Regional do Cariri

Daniely Sampaio Arruda Tavares

Universidade Federal do Ceara

Francisco Assis Bezerra da Cunha

Universidade Regional do Cariri

Henrique Douglas Melo Coutinho

Regional University of Cariri: Universidade Regional do Cariri

Sidney Gonçalo de Lima

Universidade Federal do Piauí: Universidade Federal do Piaui

Francisco Nascimento Pereira Junior

Universidade Federal do Cariri

Fabiola Fernandes Galvão Rodrigues

Universidade Regional do Cariri

George Joaquim Garcia Santos

Universidade Federal do Cariri 
Keywords: Antibacterial agents, Drosophila melanogaster, Ocimum gratisismumum L., Essential oils.

Posted Date: February 23rd, 2022

DOI: https://doi.org/10.21203/rs.3.rs-1383046/v1

License: (c) (1) This work is licensed under a Creative Commons Attribution 4.0 International License. Read Full License 
1 Evaluation of antibacterial and toxicological activities of essential oil of Ocimum gratissimum L. and its major constituent Eugenol

$4 \quad$ Julio Cesar Silva ${ }^{1, *}$; Raimundo Luiz Silva Pereira ${ }^{1}$; Thiago Sampaio de Freitas ${ }^{1}$; Janaína

5 Esmeraldo Rocha ${ }^{1}$; Nair Silva Macedo ${ }^{1}$; Carla de Fatima Alves Nonato ${ }^{1}$; Marina Leite 6 Linhares ${ }^{2}$; Daniely Sampaio Arruda Tavares ${ }^{3}$; Francisco Assis Bezerra da Cunha a; 7 Henrique Douglas Melo Coutinho ${ }^{1}$; Sidney Gonçalo de Lima ${ }^{4}$; Francisco Nascimento 8 Pereira-Junior ${ }^{5 ;}$ Fabiola Fernandes Galvão Rodrigues ${ }^{1}$; George Joaquim Garcia Santos 9

${ }^{1}$ Department of Biological Chemistry, Regional University of Cariri, R. Cel. Antonio Luis 1161, 63105000 Crato, CE, Brazil

${ }^{2}$ University Center Doutor Leão Sampaio, Av. Leão Sampaio 400, 63040000 Juazeiro do Norte, CE, Brazil

${ }^{3}$ Research and Development Center for Medicines, Federal University of Ceara, R. Coronel Nunes de Melo 1000, 60430275 Fortaleza, CE, Brazil

${ }^{4}$ Chemistry department, Federal University of Piaui, Campus Universitário Ministro Petrônio Portella, 64049550 Teresina, PI, Brazil

${ }^{5}$ Center for Agricultural and Biodiversity Sciences - CCAB, Federal University of Cariri, Crato, Ceará, 19 Brazil;

\section{Abstract}

The aim of this study was to evaluate the direct antibacterial activity, antibiotic modulation and toxicity of the essential oil of Ocimum gratissimum L. and its major compound Eugenol. The phytochemical analysis of the essential oil from leaves was investigated by Gas Chromatography coupled to Mass Spectrometry (CG-MS) and Eugenol was the major compound (63.25\%). The Minimum Inhibitory Concentration and clinical antibiotics modulatory activities were performed using the 96-well plate microdilution methodology. Drosophila melanogaster was used as a model to assess the toxicity of the two substances. In conclusion, the eugenol and essential oil of Ocimum gratissimum L. showed direct antibacterial activity and associates with the tested antibiotics, which place them as promising agents against bacterial resistance. The

* Corresponding author at: Laboratório de Microbiologia e Biologia Molecular - LMBM, Universidade Regional do Cariri - URCA, Av. Cel. Antonio ^ Luiz, 1161, Pimenta, Crato, CE. CEP: 63105-000, Brazil. E-mail address: juliocesar.silva@urca.br (H.D.M. Coutinho). 
essential oil showed less toxicity to fruit flies when compared to eugenol alone, although the results were numerically similar.

Keywords: Antibacterial agents. Drosophila melanogaster. Ocimum gratisismumum L.. Essential oils.

\section{Introduction}

As ancient as the history of civilizations, medicinal plants have always been seen for their properties in offering relevant medicinal resources to ancient people (BADKE $e t$ al., 2011). This perception collaborated with the dissemination of the therapeutic use of plant resources, which was established as a traditional secular practice and common to a diversity of cultures (BARRETO et al., 2010).

With the development of research, it is now known that the usefulness offered by medicinal plants in the treatment of diseases is associated with the fact that they are considerable sources of secondary metabolites, which protect plants, in addition to being the target of clinical and therapeutic interests (RIMAWI et al., 2020).

The discovery of new drugs for the treatment of bacterial infections has ensured the improvement of human health and the prolongation of its life (HE et al., 2020). The need to discover new treatments for diseases occurs in theory due to the involvement of resistance, low responsiveness to drugs, such as those that treat problems such as cancer, and to the many adverse effects offered by the drugs currently commercialized (ZUHAIRI et al., 2020).

In particular, bacterial resistance stands out in this context. The incidence of cases of antibiotic resistant bacterial have been observed whit increasing frequency over the past several decades, due to the prescription and incorrect use of antibiotics (OBEIDAT et al., 2012). The worsening of this scenario has an impact on the inefficiency of the drugs used, leading to the discovery of new drugs, through the screening of possible phytochemicals and the manipulation of the apparatus made available by plant products (ACHMIT et al., 2021). As a result, research that evaluates the antibacterial activity of essential oils has increased considerably (KUHN et al., 2019).

In general, essential oils are volatile compounds of different combinations, obtained from flowers, leaves and barks, which may involve the presence of monoterpenes, sesquiterpenes, phenylpropanoids and others (BIZZO et al., 2009). 
Investigations have been carried out to determine the chemical profile of these oils and how they can be used in different areas, such as industry, pharmacy and food (KUCUKBAY et al., 2014). Essential oils are abundant in different plant species, constituting most of the chemical substances of medicinal plants (SWAMY et al., 2020).

In this context, the Lamiaceae family has gained evidence, for its usefulness to the human being in offering medicinal properties and cosmetic. It is estimated that this family has a total of 200 genera and more than 6900 species distributed around the world (MOHAMMADHOSSEINI, 2017). Among these is Ocimum gratissimum L., herbaceous, perennial and with a woody base, originally from the African continent and subspontaneous in Brazil, mainly in the Northeast region (SHARMA et al., 2011).

Borges et al. (2012) distinguished Eugenol as the most expressive chemical constituent of Ocimum gratissimum L. (alfavaca). This phenolic, aromatic and lipophilic phyto-compound has shown substantial biological activities, including antibacterial (ZHANG et al., 2018).

Although encouraged, the widespread use of medicinal plants, such as their chemical components, can generate toxic responses (CUNHA et al., 2015). In view of this problem, the Drosophila melanogaster (fruit fly) model has been consecrated in evaluating the pharmacological and toxicological effects offered by metabolites or inputs derived from medicinal plants (ZEMOLIN et al., 2014).

In this way, this study characterized the chemical profile of the essential oil of Ocimum gratissimum L., presenting the possibility of its antibacterial effect and of its activity associated with antibiotics. Similar analysis was performed for Eugenol alone, comparing its effect with the results presented for essential oil. Finally, essential oil and Eugenol were analyzed through their effects on the induction of mortality or interference in the negative geotaxis mechanism of fruit flies.

\section{Materials and methods}

\section{Botanical material}

Two hundred and ten grams (210 g) of Ocimum gratissimum L. leaves were collected in July 2020 at the Crato Municipal Nursery, located at the Chico Mendes Institute for Biodiversity Conservation - ICMBio, according to coordinates $7^{\circ} 14^{\prime} 27.7^{\prime \prime} \mathrm{S}$ $39^{\circ} 25^{\prime} 01.4^{\prime \prime}$. The leaves were collected at 12:00 PM, Eugenol peak time, as stipulated by Borges and collaborators (2012). An excicata of the specimen was deposited at the 
101 Herbarium Dardano de Andrade de Lima - HCDAL of the Regional University of Cariri

102

103

104

105

106

107

108

109

110

111

112

113

114

115

116

117

118

119

120

121

122

123

124

125

126

127

- URCA, Crato/CE, under number 14.389.

\section{Essential Oil Extraction And Obtaining The Eugenol}

The extraction of the essential oil of Ocimum gratissimum L. was carried out by the hydrodistillation method, using the Clevenger-type apparatus. The leaves were crushed, placed in a 5.0 L glass flask and placed in contact with $2.5 \mathrm{~L}$ of distilled water for subsequent boiling for 2 hours. The oil was separated by adding sodium sulfate $\left(\mathrm{Na}_{2} \mathrm{SO}_{4}\right)$ anhydrous and preserved in refrigeration $\left(-4^{\circ} \mathrm{C}\right)$ until its use. Eugenol (SigmaAldrich) was kindly provided by Dr. Francisco Assis Bezerra da Cunha from the SemiArid Bioprospecting and Alternative Methods Laboratory - LABSEMA, Regional University of Cariri (URCA), Crato/CE.

\section{Chemical analysis of the essential oil of Ocimum gratissimum L.}

Analyzes in CG/EM were performed on the chromatograph (GCMS-QP2010 SE, AOC-5000 auto injector from SHIMADZU), following the following analysis conditions: Injector $250{ }^{\circ} \mathrm{C}$; initial oven temperature of $50{ }^{\circ} \mathrm{C}$, with a first heating ramp of $5{ }^{\circ} \mathrm{C} / \mathrm{min}$ to $180{ }^{\circ} \mathrm{C}$, remaining for 4 minutes; a second ramp of $10^{\circ} \mathrm{C} / \mathrm{min}$ to $260{ }^{\circ} \mathrm{C}$, remaining for 10 minutes; Split ratio of 1:100; interface temperature: $250{ }^{\circ} \mathrm{C}$ and $250{ }^{\circ} \mathrm{C}$ source; mass range from 50 to 400 Daltons; ionization by electron impacts, $70 \mathrm{eV}$. For component chromatography, a DB5-MS (Agilent) column, $30 \mathrm{~m} \times 0.25 \mathrm{~mm}$ with an inner film thickness of $0.25 \mu \mathrm{m}$ and a stationary phase of diphenyl dimethylpolysiloxane and helium as carrier gas was used. The identification was carried out by comparing the mass spectra with those of the Nist08 libraries and comparison with the base records of the literature.

\section{Preparation of the essential oil of Ocimum gratissimum L. and Eugenol}

In a test tube $10 \mathrm{mg}$ of essential oil and $500 \mu \mathrm{L}$ of DMSO were added. This solution was transferred to another tube and diluted in $9265 \mathrm{~mL}$ of sterile distilled water, resulting in a solution with a final concentration of $1,024 \mu \mathrm{g} / \mathrm{mL}$ that was used in all tests. The same process was repeated for Eugenol. 


\section{Determination of the minimum inhibitory concentration (CIM)}

The bacterial strains Escherichia coli ATCC 25922, Escherichia coli 06, Klebsiella pneumoniae ATCC 4352, Pseudomonas aeruginosa ATCC 9027, Pseudomonas aeruginosa 24, Staphylococcus aureus ATCC 25923, Staphylococcus aureus 10 and Streptococcus mutans ATCC 0446 were seeded in Petri dishes containing HIA culture medium and incubated at $37{ }^{\circ} \mathrm{C}$ for $24 \mathrm{~h}$.

Then, a sample of each culture was dragged and diluted in test tubes containing sterile saline, in triplicate. After this procedure, the turbidity was adjusted according to the McFarland 0.5 scale. A $100 \mu \mathrm{L}$ aliquot of each bacterial inoculum (referring to $10 \%$ of the total solution) was transferred to a tube containing $900 \mu \mathrm{L}$ of a $10 \%$ Brain and Heart Infusion Broth (BHI) solution.

Each well of a 96-well microdilution plate was filled with $100 \mu \mathrm{L}$ of the solution formed, and then the essential oil was microdiluted in a 1:1 ratio, the concentrations ranged from $512 \mu \mathrm{g} / \mathrm{mL}$ to $8 \mu \mathrm{g} / \mathrm{mL}$. A well with no essential oil added was used as a positive control of bacterial growth. The same process performed for the essential oil was repeated with Eugenol. The reading of the Minimum Inhibitory Concentration (MIC) was performed by colorimetric method after 24 hours of incubation at $37{ }^{\circ} \mathrm{C}$ in a bacteriological oven. Bacterial growth was analyzed by adding $20 \mu \mathrm{L}$ of resazurin $(0.4$ $\mathrm{mg} / \mathrm{ml}$ ) to each well. After the addition of resazurin, the plates were incubated for $1 \mathrm{~h}$ at room temperature and after this period the colorimetric variation was observed, since there was no bacterial growth in the wells that remained blue, and there was bacterial growth in the wells that changed from blue to pink coloring (GALUCCI et al., 2009.). The tests were performed in triplicate.

\section{Evaluation of modulating antibiotic activity}

To evaluate the activity associated with antibiotics, the method described by Coutinho and collaborators et al. (2010). The substances (Chlorpromazine, Eugenol and essential oil) were tested in their sub-inhibitory concentrations (MIC/8). Each substance was diluted in tubes containing $900 \mu \mathrm{L}$ of BHI $10 \%$, where $100 \mu \mathrm{L}$ of the bacterial inoculum of the strains Escherichia coli 06, Pseudomonas aeruginosa 24 and Staphylococcus aureus 10 were added separately. $100 \mu \mathrm{L}$ of the obtained concentration were placed in each well of the microdilution plate. Microdilutions were performed with 
169

170

171

172

173

174

175

176

177

178

179

180

181

182

183

184

185

186

187

188

189

190

191

192

193

194

195

196

197

198

199

200

201

202

antibiotics Amikacin, Ampicillin, Norfloxacin and Penicillin and the enzymatic inhibitor Sulbactam (associated with Ampicillin), all of them with an initial concentration of 1,024 $\mu \mathrm{L} / \mathrm{mL}$. The last well of each plate was used as a growth control. The plates were incubated in an oven at $37^{\circ} \mathrm{C}$ for 24 hours and the Minimum Inhibitory Concentrations of each tested substance were determined by colorimetric method, through the addition of resazurin (GALUCCI et al., 2009). The tests were performed in triplicate.

\section{Toxicity assay}

\section{Breeding and stocking of Drosophila melanogaster}

Drosophila melanogaster (Harwich strain) was obtained from the National Species Stock Center, Bowling Green, OH. The flies were grown according to methodology described by Cunha et al. (2015) in $340 \mathrm{~mL}$ glass containers and grown in medium containing: $83 \%$ corn mass, $4 \%$ sugar, $4 \%$ lyophilized milk, $4 \%$ soybean, $4 \%$ wheat or oat bran and $1 \%$ salt). When cooking the mixture, $1 \mathrm{~g}$ of Nipagin (Methylparaben) was added. After the mixture cooled in the growth flasks, $1 \mathrm{~mL}$ of a solution containing Saccharomyces cerevisiae was added.

The flies were grown in BOD type incubator at a temperature of $25^{\circ} \mathrm{C} \pm 1{ }^{\circ} \mathrm{C}$, with light-dark cycles $12: 12 \mathrm{~h}$ and a relative humidity of $60 \%$.

\section{Mortality assay}

Mortality tests were performed in accordance with the methodology of Cunha et al. (2015). Adult flies, male and female, were placed in $130 \mathrm{~mL}$ containers $(6 \mathrm{~cm}$ high and $6.5 \mathrm{~cm}$ in diameter). The pots were divided into control and test groups. One milliliter $(1 \mathrm{~mL})$ of $20 \%$ sucrose solution in distilled water was placed at the bottom of all control pots. The test groups consisted of pots that contained eugenol or essential oil of Ocimum gratissimum L. The fumigation methodology was adopted, where the compounds are added on a filter paper in the tube cap and thus are volatilized and absorbed. The concentrations of 1,5 and $10 \mu \mathrm{L} / \mathrm{mL}$ of Eugenol and essential oil of $O$. gratissimum were used, with a counting time of $1,2,3,6,9,12,24$ and $48 \mathrm{~h}$. The temperature of $25^{\circ}$ $\mathrm{C} \pm 1{ }^{\circ} \mathrm{C}$ was maintained throughout the test, as well as the relative humidity of $60 \%$ in a BOD type incubator with a light-dark cycles $12: 12 \mathrm{~h}$. The tests were performed in sextuplicate, with each pot containing a total of 20 flies. 
203

204

205

206

207

208

209

210

211

212

213

214

215

216

217

218

219

220

221

222

223

224

225

226

227

228

229

\section{Negative geotaxis assay}

Damage to the locomotor system was determined by the negative geotaxis test, as described by Cunha et al. (2015). Live flies, after exposure to Eugenol or essential oil of O. gratissimum at predetermined times, were taken to the bottom of the pots. After one minute, the flies that reached $4 \mathrm{~cm}$ in height in the containers were counted and this procedure was repeated after the 1-minute interval.

\section{Statistical analysis}

(1)

The antibacterial assays were performed in triplicates and the results were expressed as the geometric mean. Statistical hypothesis analysis was performed for the antibacterial assays using a Two-Way ANOVA followed by Bonferroni's post hoc test, using the GraphPad Prism 7.0 software. To analyze the toxicity data, a two-way ANOVA followed by Tukey's multiple comparisons test was performed. No statistical differences using the same concentration as a function of time were observed.

\section{Results}

The yield of the essential oil of Ocimum gratisismum (EOOg) was $0.39 \%$. Phytochemical characterization, performed by mass chromatography, identified the presence of 10 compounds, as can be seen in Figure 1.

When analyzing the constituents individually, it is observed that Eugenol $(63.25 \%)$, Cineole (10.83\%), Beta-silinene $(8.43 \%)$ and Trans-caryophyllene $(6.85 \%)$ are the major components (Table 1).

\begin{tabular}{|c|c|c|c|c|c|c|c|}
\hline $\mathbf{N}^{\mathbf{0}}$ & $\mathbf{R T}$ & $\begin{array}{c}\text { Similarity } \\
(\boldsymbol{\%})\end{array}$ & Constituent & $\begin{array}{c}\text { Kovats } \\
\text { Index }\end{array}$ & $\begin{array}{c}\text { Molecular } \\
\text { Formula }\end{array}$ & $\begin{array}{c}\text { Absolute } \\
\text { Area }\end{array}$ & Relative Area \\
\hline $\mathbf{1}$ & 9.525 & 95 & $\begin{array}{c}1,8 \text {-cineole- } \\
\text { eucalytol }\end{array}$ & 991 & $\mathrm{C}_{10} \mathrm{H}_{18} \mathrm{O}$ & 648767 & $10,83 \%$ \\
\hline $\mathbf{2}$ & 9.574 & 93 & Cis-ocimene & 1050 & $\mathrm{C}_{10} \mathrm{H}_{16}$ & 112333 & $1,88 \%$ \\
\hline
\end{tabular}




\begin{tabular}{|c|c|c|c|c|c|c|c|}
\hline $\mathbf{3}$ & 14.428 & 93 & $\begin{array}{c}\text { l-alpha- } \\
\text { terpineol }\end{array}$ & 1189 & $\mathrm{C}_{10} \mathrm{H}_{18} \mathrm{O}$ & 50805 & $0,85 \%$ \\
\hline $\mathbf{4}$ & 18.955 & 97 & Eugenol & 1356 & $\mathrm{C}_{10} \mathrm{H}_{12} \mathrm{O}_{2}$ & 3787946 & $63,25 \%$ \\
\hline $\mathbf{5}$ & 20.077 & 91 & Beta-elemene & 1375 & $\mathrm{C}_{15} \mathrm{H}_{24}$ & 50833 & $0,85 \%$ \\
\hline $\mathbf{6}$ & 20.959 & 96 & $\begin{array}{c}\text { Trans- } \\
\text { caryophyllene }\end{array}$ & 1419 & $\mathrm{C}_{15} \mathrm{H}_{24}$ & 410342 & $6,85 \%$ \\
\hline $\mathbf{7}$ & 21.921 & 94 & $\begin{array}{c}\text { Alpha- } \\
\text { humulene }\end{array}$ & 1438 & $\mathrm{C}_{15} \mathrm{H}_{24}$ & 60036 & $1,00 \%$ \\
\hline $\mathbf{8}$ & 22.585 & 96 & Germacrene-D & 1480 & $\mathrm{C}_{15} \mathrm{H}_{2} 4$ & 182146 & $3,04 \%$ \\
\hline $\mathbf{9}$ & 22.810 & 95 & Beta-selinene & 1485 & $\mathrm{C}_{15} \mathrm{H}_{24}$ & 504974 & $8,43 \%$ \\
\hline $\mathbf{1 0}$ & 22.985 & 94 & Alpha-selinene & 1494 & $\mathrm{C}_{15} \mathrm{H}_{24}$ & 180493 & $3,01 \%$ \\
\hline
\end{tabular}

230 Table 1: Relative composition of Ocimum gratissimum L. essential oil.

231 Source: Elaborated by the author (2021).

232

233

The analysis of the Minimum Inhibitory Concentration (MIC) was performed

234 using the microdilution method. The values obtained for the MICs of each substance were

235 considered clinically significant when less than $1,000 \mu \mathrm{g} / \mathrm{mL}$ (HOUGHTON et al., 2007).

236 The Minimum Inhibitory Concentration (MIC) obtained in the tests with Eugenol (EUG)

237 demonstrated its action against the strains: Klebsiella pneumoniae ATCC 4352,

238 Pseudomonas aeruginosa ATCC 9027, Pseudomonas aeruginosa 24, Staphylococcus

239 aureus ATCC 25923 and Streptococcus mutans ATCC 0446 (Table 2a).

240 Following the analysis of antibacterial activity, the EOOg showed results similar

241 to those obtained by the EUG, with clinically significant responses evidenced against the

242 same strains tested (Table 2b).

243

244 Table 2: Minimum inhibitory concentration (MIC) of Eugenol and Essential Oil of

245 Ocimum gratissimum L. against bacterial strains. 


\begin{tabular}{|c|c|c|}
\hline & STRAINS & MIC \\
\hline 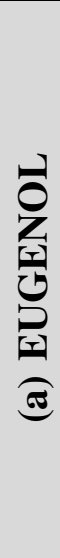 & $\begin{array}{c}\text { Escherichia coli ATCC } 25922 \\
\text { Escherichia coli } 06 \\
\text { Klebsiella pneumoniae ATCC } 4352 \\
\text { Pseudomonas aeruginosa ATCC } 9027 \\
\text { Pseudomonas aeruginosa } 24 \\
\text { Staphylococcus aureus ATCC } 25923 \\
\text { Staphylococcus aureus } 10 \\
\text { Streptococcus mutans ATCC } 0446\end{array}$ & $\begin{array}{c}1,024.00 \mu \mathrm{g} / \mathrm{mL} \\
1,024.00 \mu \mathrm{g} / \mathrm{mL} \\
512.00 \mu \mathrm{g} / \mathrm{mL} \\
406.37 \mu \mathrm{g} / \mathrm{mL} \\
322.54 \mu \mathrm{g} / \mathrm{mL} \\
203.19 \mu \mathrm{g} / \mathrm{mL} \\
1,024.00 \mu \mathrm{g} / \mathrm{mL} \\
322.54 \mu \mathrm{g} / \mathrm{mL}\end{array}$ \\
\hline $\begin{array}{l}3 \\
0 \\
0 \\
2 \\
2 \\
0 \\
0 \\
0 \\
0 \\
0 \\
0 \\
0\end{array}$ & $\begin{array}{c}\text { Escherichia coli ATCC } 25922 \\
\text { Escherichia coli } 06 \\
\text { Klebsiella pneumoniae ATCC } 4352 \\
\text { Pseudomonas aeruginosa ATCC } 9027 \\
\text { Pseudomonas aeruginosa } 24 \\
\text { Staphylococcus aureus ATCC } 25923 \\
\text { Staphylococcus aureus } 10 \\
\text { Streptococcus mutans ATCC } 0446\end{array}$ & $\begin{array}{c}1,024.00 \mu \mathrm{g} / \mathrm{mL} \\
1,024.00 \mu \mathrm{g} / \mathrm{mL} \\
645.08 \mu \mathrm{g} / \mathrm{mL} \\
812.75 \mu \mathrm{g} / \mathrm{mL} \\
512.00 \mu \mathrm{g} / \mathrm{mL} \\
80.63 \mu \mathrm{g} / \mathrm{mL} \\
1,024.00 \mu \mathrm{g} / \mathrm{mL} \\
812.75 \mu \mathrm{g} / \mathrm{mL}\end{array}$ \\
\hline
\end{tabular}

Source: Elaborated by the author (2021).

An evaluation of the associated activity of EUG and EOOg with antibiotics was also carried out. In addition, the effect of the combination of chlorpromazine (CPMZ), associated with the antibiotics of interest, and Sulbactam (SULB) in combination with Ampicillin was also tested. The results obtained in this analysis were distributed in sections, organized according to pairs of antibiotics, which act on the external and internal portion of the bacterial cell.

Figures $2 \mathrm{a}$ and $2 \mathrm{~b}$ represent the results of the combination of the compounds mentioned above, against the Escherichia coli 06 strain. A possible synergistic effect was evidenced in the association between CPMZ + Norfloxacin, and EUG + Norfloxacin. The same could be seen with Amikacin, when associated with EUG and EOOg. On the other hand, CPMZ when associated with Amikacin, caused an increase in MIC, resulting in a possible antagonistic phenomenon (Figure 2a).

It was observed that the combination of Sulbactam and Ampicillin caused a reduction in MIC, from $1,024 \mu \mathrm{g} / \mathrm{mL}$ to $128 \mu \mathrm{g} / \mathrm{mL}$, possibly potentiating the activity of ampicillin against the strain tested (Figure $2 b$ ). 
Figures $2 \mathrm{c}$ and $2 \mathrm{~d}$ show a combined activity of the antibiotics Norfloxacin, Amikacin, Penicillin and Ampicillin, for the bacteria Pseudomonas auruginosa 24. Chlorpromazine continued to intensify the action of Norfloxacin, as well as with Escherichia coli 06 . This possible synergistic effect was also evidenced in the association $\mathrm{CPMZ}+$ Amikacin and EUG + Amikacin. However, the EUG + Norfloxacin combination was possibly antagonistic, with a corresponding increase in the inhibitory concentration of the antibiotic against the strain tested. This information can be seen in Figure 2c.

Sulbactam continued to intensify the action of Ampicillin, by reducing the MIC from $512 \mu \mathrm{g} / \mathrm{mL}$ to $4 \mu \mathrm{g} / \mathrm{mL}$, on the other hand, there was a possible antagonistic process in the association of this antibiotic with the EUG, given the increase in MIC from 512 $\mu \mathrm{g} / \mathrm{mL}$ to $812.7 \mu \mathrm{g} / \mathrm{mL}$ (Figure $2 \mathrm{~d}$ ).

Figure $2 \mathrm{e}$ shows a possible antagonism in the combination of Norfloxacin + CPMZ and Norfloxacin + EUG against Staphylococcus aureus 10. This antagonism was repeated for Amikacin + CPMZ and Amikacin + EUG. However, there was an intensification of Amikacin activity, when combined with essential oil, similarly to what happened in the Echerichia coli 06 strain.

Interestingly, EUG and EOOg caused a possible synergistic effect (reduction of MIC from $1,024 \mu \mathrm{g} / \mathrm{mL}$ to $161.3 \mu \mathrm{g} / \mathrm{mL}$ and $128 \mu \mathrm{g} / \mathrm{mL}$, respectively) when combined with Penicillin against Staphylococcus aureus 10 (Figure 2f) which it did not happen with the strains Escherichia coli 06 and Pseudomonas aeruginosa 24. In view of the Grampositivity of Staphylococcus aureus, it is assumed that this effect for Penicillin is not prominent in Gram-negatives. The combination of Sulbactam + Ampicillin and EOOg + Ampicillin also potentiated the control effect, the latter contrary to what was seen in the other strains.

The Drosophila melanogaster model was chosen to assess the toxicity of EUG and EOOg. For both, concentrations of 1, 5 and $10 \mu \mathrm{L} / \mathrm{mL}$ were used. EOOg showed a EC50 equal to $2,677 \mu \mathrm{L} / \mathrm{mL}$ after $6 \mathrm{~h}$ of exposure. The concentration of $1 \mu \mathrm{L} / \mathrm{mL}$ did not differ significantly when compared to the control. The concentration of $5 \mu \mathrm{L} / \mathrm{mL}$ showed greater toxicity after 48 hours of contact. After 6 hours of exposure to a concentration of $10 \mu \mathrm{L} / \mathrm{mL}$ of EOOg, it started to increase significantly, demonstrating the toxicity at this concentration. (Figure 3a).

There was variation in the mortality pattern according to the EUG concentration used, which presented EC50 equivalent to 2,681 $\mu \mathrm{L} / \mathrm{mL}$, after $6 \mathrm{~h}$ of exposure. Concentrations of 1 and $5 \mu \mathrm{L} / \mathrm{mL}$ showed a significant degree of mortality after 48 and 
304

305

306

307

308

309

310

311

312

313

314

315

316

317

318

319

320

321

322

323

324

325

326

327

328

329

330

331

332

333

334

24 hours of exposure, respectively. On the other hand, the concentration of $10 \mu \mathrm{L}$ differed from the control after 6 hours, being more toxic in relation to the others (Figure $3 b$ ). Thus, EOOg was less offensive when compared to EUG.

The concentration of $1 \mu \mathrm{L} / \mathrm{mL}$ of EOOg was not significant in the impairment of D. melanogaster geotaxy. Fact that differs from that visualized for the concentration of 5 $\mu \mathrm{L} / \mathrm{mL}$, which caused an interference in the flight ability from $12 \mathrm{~h}$ of the beginning of the tests. The concentration of $10 \mu \mathrm{L} / \mathrm{mL}$ of EOOg caused the negative geotaxis of the fruit flies to be compromised right after the first 3 hours of testing, with a substantial degree of impairment (Figure 4a).

The Eugenol also affected the negative geotaxis of $D$. melanogaster. Figure $4 \mathrm{~b}$ shows how much each concentration varied compared to the control. In this case, it is verified that the exposure to $1 \mu \mathrm{L} / \mathrm{mL}$ of the compound causes impairment of the mobility of the flies after 48 hours of exposure, while the concentration of $5 \mu \mathrm{L} / \mathrm{mL}$ causes the same effect after $12 \mathrm{~h}$ of contact. The previous exposure to $10 \mu \mathrm{L} / \mathrm{mL}$ of EUG was even more toxic, in view of the negative geotaxis impairment even in the first counting time.

\section{Discussion}

Pessoa et al. (2015) chemically characterized the essential oil of Ocimum gratissimum L., distinguishing the following compounds: Eugenol (67.30 to 74.99\%), $\beta$ selinene (8.18 to $8.27 \%$ ), $\beta$ - ilangene (4.97 to 5.09\%), Viridiflorene (3.38 -3.47\%), 1,8cineol (3.07 to $3.11 \%)$ and $\gamma$-himachalene $(2.00-2.62 \%)$. The relative composition of the EOOg presented in this study was similar to that presented by Pessoa et al. (2015), in view of the one presented for Eugenol (63.25\%) and $\beta$-selinene (8.43\%).

Catherine, Deepika and Negi (2012) mentioned the effectiveness of Eugenol against the bacteria Escherichia coli and Staphylococcus aureus. The performance of Eugenol in the microtiter methodology was expressive, represented in the very low values of MIC for bacteria: Bacillus cereus $(0,125 \mu \mathrm{g} / \mathrm{mL})$, Escherichia coli $(0,125 \mu \mathrm{g} / \mathrm{mL})$, Helicobacter pylori $(0,0312 \mu \mathrm{g} / \mathrm{mL})$, Staphylococcus aureus $(0,25 \mu \mathrm{g} / \mathrm{mL})$ e Streptococcus pyogenes $(0,5 \mu \mathrm{g} / \mathrm{mL})$. A slightly higher MIC was obtained for Pseudomonas aeruginosa $(8 \mu \mathrm{g} / \mathrm{mL})$, although this is as significant as those of the strains mentioned (JEYAKUMAR; LAWRENCE, 2020).

Aguiar et al. (2015) examined the antibacterial action of EOOg against bacteria (standard and resistant) Escherichia coli, Pseudomonas aeruginosa and Staphylococcus aureus. In this analysis, only the standard Staphylococcus aureus MIC was significant. 
These data corroborate with this study, and it is useful to reinforce that EOOg showed equal effectiveness in relation to the standard strains of Klebsiella pneumoniae, standard and resistant strains of Pseudomonas aeruginosa, standard strains of Staphylococcus aureus and Streptococcus mutans. In turn, Joshi (2013), concluded that the essential oil of Ocimum gratissimum L. also has considerable activity against Escherichia coli and Klebsiella pneumoniae, by dilution in tubes.

Jeyacumer and Lawrence (2020) suggest that the EUG causes a disturbance in the lipid fraction of the bacterial membrane, causing a change in permeability that facilitates the interaction of the compound with intracellular portions, thus justifying its effect. The mechanism of action of EOOg is related to its majority composition, with prevalence of Eugenol, as described by Joshi (2013).

The evaluation of the combined activity was performed for the antibiotics Amikacin, Ampicillin, Norfloxacin and Penicillin, aiming to evaluate the possibility of EUG and EOOg to intensify or not the action of these drugs. EUG is the major compound present in a chemotype of Ocimum basilicum L. Studies carried out with the latter have shown that the association of its essential oil with Neomycin and also with Amikacin generates a possible synergistic effect, evidenced by the reduction of MIC of these antibiotics, against Staphylococcus aureus (NUNES et al., 2014). This information contrasts with what was verified in this study for EOOg and even for the EUG.

Aguiar et al. (2015) studied the direct modulating effect of the essential oil of Ocimum gratissimum L. in association with the aminoglycosides Amikacin and Gentamicin. The significant results obtained in tests involving the bacteria Escherichia coli, Pseudomonas aeruginosa and Staphylococcus aureus were possibly antagonistic. In this study, we present the possibility of synergism for Amikacin (against Escherichia coli and Staphylococcus aureus), Norfloxacin (against Pseudomonas auruginosa), Ampicillin and Penicillin (against Staphylococcus aureus).

The sequence inhibition of a common biochemical pathway, as well as enzymes that protect microorganisms, the combination of active agents in the cell wall or their association with components that act in other pathways, facilitating their entry into the cell, characterize the main reasons that trigger processes of potentiation of the action of drugs (SANTIESTEBAN-LOPEZ; PALOU; LÓPEZ-MALO, 2007).

The factors that cause antagonism in the drug combination are still poorly understood. However, it is known that the association of bacteriostatic and bactericidal agents, the combined use of compounds that compete for the same target in a 
372

373

374

375

376

377

378

379

380

381

382

383

384

385

386

387

388

389

390

391

392

393

394

395

396

397

398

399

400

401

402

403

404

405

microorganism and the very molecular interactions between different active components, are the main reasons behind the development of antagonistic processes (GÕNI et al., 2009).

The effect of Eugenol, when combined with antibiotics, can be understood by what was explained by Debao et al. (2019). This phyto-compound acts by creating deformations in the bacterial membrane, such as that seen against Escherichia coli, damaging its integrity and morphology, thus causing an overflow of intracellular content and inactivation of the microorganism. Furthermore, there is also a predisposition of the EUG to bacterial genomic DNA, responsible for the aggregation of DNA molecules. Due to the lipophilic character of monoterpenes, such as EUG, the interaction with polysaccharides, fatty acids and lipids of the bacterial cell membrane is facilitated, thus causing a disturbance in the permeable barrier (LIMAVERDE et al, 2017).

An analogous mechanism can be perceived in the performance of essential oils, capable of compromising the integrity of the bacterial membrane and the conformation of its cell wall, facilitating the influx of drugs (MATIAS et al., 2011). The hydrophobic compounds of these oils, such as Eugenol, are able to adhere to both the plasma membrane and phospholipids and membrane proteins, thus promoting the assimilation of antibiotics (LUZ et al., 2014;).

The conformation of the cellular envelope of microorganisms, induce variations in the effectiveness of chemical components against bacteria. The gram-positive peptideoglycan thick layers guarantee greater sensitivity to bioactive components, since they can interact with the bacterial envelope in different ways and degrees (REQUENA; VARGAS; CHIRALT, 2019). This phenomenon justifies the performance of EOOg by potentiating the action of Amikacin and Penicillin against Staphylococcus aureus 10 and EUG by intensifying the action of Penicillin against the same strain in this study.

Chlorpromazine, in non-antibacterial concentrations, has been used as an agent capable of inhibiting efflux pumps, Coutinho et al. (2010) discussed the effect of reducing the MIC of Chlorpromazine, concluding its activity for Amikacin, Kanamycin and Tobramycin, in addition to describing an antagonistic effect for Gentamicin and Neomycin, with data referring to tests with Escherichia coli.

Sulbactam is a semi-synthetic compound capable of inhibiting the beta-lactamase enzyme (KU; YU, 2021). The combination of SULB together with Ampicillin considerably expands the spectrum of action of the latter, against Klebsiella pneumoniae and Staphylococcus aureus, for example. The possible synergistic interactions, presented 
406

407

408

409

410

411

412

413

414

415

416

417

418

419

420

421

422

423

424

425

426

427

428

429

430

431

432

433

434

435

436

437

in this study, involving CPMZ and SULB, may be suggestive of efflux pump and betalactamase enzyme inhibition processes, respectively. However, specific studies must be carried out to prove these mechanisms of action.

According to Zhang et al. (2016), oxygenated monoterpenes are agents of considerable toxicity against Drosophila melanogaster, which can be represented by the variation of $\mathrm{LC}_{50}$ of 0.015 and $0.02 \mu \mathrm{l} / \mathrm{L}$. This data is consistent with that presented to the EUG in this study, taking into account the $\mathrm{EC}_{50}$ value equivalent to $2,681 \mu \mathrm{L} / \mathrm{mL}$. The main factor behind this is associated with the specific characteristics of the EUG, such as: the presence of the hydroxyl group and its position, as well as the characteristic positioning of its double bonds, which can vary in a different way in the degree of mortality of fruit flies, as seen for $\alpha$-pinene and $\beta$-pinene (XIE et al., 2014, ZHANG et al., 2016).

The toxicological response of essential oils is related to the additive and synergistic effects of different compounds (ESSOUNG et al., 2020). Tests carried out with Ocimum tenuiflorum showed their fumigant capacity against S. oryzae, by inhibiting the enzyme acetylcholinesterase (AChE). This action is represented by the $\mathrm{LC}_{50}$ value of $479 \mu \mathrm{L} / \mathrm{L}$ (BHAVYA; CHANDU; DEVI, 2018).

A similar effect was evidenced for EOOg in this study, whose mortality was similar to that of the EUG, which is justified, since the literature describes the EUG as one of the main compounds of Ocimum gratissimum L. In particular, the compounds present in oils essential elements confer volatile characteristics, which facilitate their entry into the intracellular environment, the influx of terpenes, for example, can cause the formation of free radicals, leading to death (HUA et al. 2018).

The toxicological effect on the negative geotaxis of Drosophila melanogaster was prominent for EUG and EOOg. As a survival strategy in adverse situations, fruit flies increase the activity levels of the enzyme acetylcholinesterase (AChE), thus hydrolyzing acetylcholine and preventing it from accumulating in unfavorable environmental conditions or stress (HU et al., 2019). Thus, it is suggested that the EUG and OEOg acted by inhibiting the action of AChE, allowing the stress of the flies with impairment of their locomotor system. 
Eugenol is the most expressive component of the essential oil of Ocimum gratissimum L. The results obtained in the tests of antibacterial activity and combined with antibiotics were promising, demonstrating that both EUG and EOOg can be viable alternatives for reversing bacterial resistance. Even so, further studies should be carried out to better evaluate the performance of the tested substances, as well as to delimit the toxicological effect in relation to other concentrations and also by using other model organisms.

\section{Authorship contribution declaration}

Júlio César Silva: Methodology and validation. Raimundo Luiz Silva Pereira: Methodology. Thiago Sampaio de Freitas: Software. Janaína Esmeraldo Rocha: Validation. Nair Silva Macedo: Methodology. Carla de Fatima Alves Nonato: Methodology. Marina Leite Linhares: Formal analysis. Daniely Sampaio Arruda Tavares: Formal analysis. Francisco Assis Bezerra da Cunha: Resources, Supervision. Henrique Douglas Melo Coutinho: Conceptualization, Supervision. Sidney Gonçalo de Lima: Resources, Supervision. Francisco Nascimento Pereira Júnior: Writingreview and editing. Fabiola Fernandes Galvão Rodrigues: Conceptualization, Supervision. George Joaquim Garcia Santos: Conceptualization, Supervision.

\section{Declaration}

Competing interest: The authors declare that they have no known competing financial interests or personal relationships that could have appeared to influence the work reported in this paper.

Acknowledgments: This study was funded by the Fundação Cearense de Apoio ao Desenvolvimento Científico e Tecnológico - FUNCAP; Conselho Nacional de Desenvolvimento Científico e Tecnológico - CNPq.

\section{References}

Achmit M, Aoussara N, Melloukia F, Mhanda RA, Ibáñez MD, Blázquez MA, Akssira M, Zerouali K, Rhallabi N (2021) In vitro antibacterial and biofilm inhibitory activity of the sawdust essential oil of Tetraclinis articulata (Vahl) against catheter-associated Staphylococcus aureus clinical isolates. Curr Res Biotec 3:1-5 
Aguiar JJS, Sousa CPB, Araruna MKA, Silva MKN, Portelo AC, Lopes JC, Carvalho VRA, Figueredo FG, Bitu VCN, Coutinho HDM, Miranda TAS, Matias EFF (2015) Antibacterial and modifying-antibiotic activities of the essential oils of Ocimum gratissimum L. and Plectranthus amboinicus L. Eur J Integr Med 7:151-156

Badke MR, Budó MLD, Silva FM, Ressel LB (2011) Plantas medicinais: O saber sustentado na prática do cotidiano popular. Esc Ana Nery Rev Enf 15:132-139

Barreto FS, Sousa EO, Campos AR, Costa JGM, Rodrigues FFG (2010) Antibacterial activity of Lantana camara Linn. and Lantana montevidensis brig extracts from CaririCeará, Brazil. J Young Pharm 2:42-44

Bhavya ML, Chandu AGS, Devi SS (2018) Ocimum tenuiflorum oil, a potential insecticide against rice weevil with anti-acetylcholinesterase activity. Ind Crops Prod 126:434-439

Bizzo HR, Hovell AMC, Rezende CM (2009) Óleos essenciais no Brasil: aspectos gerais, desenvolvimento e perspectivas. Quim Nova 32:588-594

Borges AM, Pereira J, Cardoso MG, Alves JA, Lucena EMP (2012) Determinação de óleos essenciais de alfavaca (Ocimum gratissimum L.), orégano (Origanum vulgare L.) e tomilho (Thymus vulgaris L.). Rev. bras. plantas med 14:656-665

Catherine AA, Deepika H, Negi PS (2012) Antibacterial activity of eugenol and peppermint oil in model food systems. J Essent Oil Research 24:481-486

Coutinho HDM, Costa JGM, Falcão-Silva VS, Siqueira-Júnior JP, Lima EO (2010) In vitro additive effect of Hyptis martiusii in the resistance to aminoglycosides of methicillin-resistant Staphylococcus aureus. Pharm Biol 48:1002-1006

Cunha FAB, Wallau GL, Pinho AI, Nunes MEM, Leite NF, Tintino SR, Costa GM, Athayde ML, Boligon AA, Coutinho HDM, Pereira AB, Posser T, Franco JL (2015) Eugenia uniflora leaves essential oil induces toxicity in Drosophila melanogaster: involvement of oxidative stress mechanisms. Toxicol Res 4:634-644

Niu D, Wang Q-Y, Ren E-F, Zeng X-A, Wang L-H, He T-F, Wen Q-H, Brennan CS (2019) Multi-target antibacterial mechanism of eugenol and its combined inactivation with pulsed electric fields in a hurdle strategy on Escherichia coli. Food Control 106:1-7

Essoung FRE, Tadjong AT, Chhabra SC, Mohamed SA, Hassanali A (2020) Repellence and fumigant toxicity of essential oils of Ocimum gratissimum and Ocimum kilimandscharicum on Tuta absoluta (Lepidoptera: Gelechiidae). Environ Sci Pollut Res Int 27:37963-37976

Gallucci MN, Oliva M, Casero C, Dambolena J, Luna A, Zygadlo J, Demo M (2009) Antimicrobial combined action of terpenes against the food-borne microorganisms Escherichia coli, Staphylococcus aureus and Bacillus cereus. Flavour Fragr J 24:348-354 
Goñi P, López P, Sánchez C, Gómez-Lus R, Becerril R, Nerín C (2009) Antimicrobial activity in the vapour phase of a combination of Cinnamon and clove essential oils. Food Chem 116:982-989

He F, Wang W, Wu M, Fang Y, Wang S, Yang Y, Ye C, Xiang F (2020) Antioxidant and antibacterial activities of essential oil from Atractylodes lancea rhizomes. Ind Crops Prod $153: 1-8$

Hu X, Fu W, Yang X, Mu Y, Gu W, Zhang M (2019) Effects of cadmium on fecundity and defence ability of Drosophila melanogaster. Ecotoxicol Environ Saf 171:871-877

Houghton PJ, Howes M-J, Lee CC, Steventon G (2007) Uses and abuses of in vitro tests in ethnopharmacology: Visualizing an elephant (Review). J Ethnopharmacol 110:391400

Hua Q, Liu Y-G, Yan Z-L, Zeng G-M, Liu S-B, Wang W-J, Tan X-F, Deng J-Q, Tang X, Wang Q-P (2018) Allelopathic effect of the rice straw aqueous extract on the growth of Microcystis aeruginosa. Ecotoxicol Environ Saf 148:953-959

Jeyakumar GE, Lawrence R (2021) Mechanisms of bactericidal action of Eugenol against Escherichia coli. J Herbal Med 26:1-25

Joshi RK (2013) Chemical composition, in vitro antimicrobial and antioxidant activities of the essential oils of Ocimum Gratissimum, O. Sanctum and their major constituents. Indian J Pharm Sci 75:457-462

$\mathrm{Ku} \mathrm{Y}-\mathrm{H}$, Yu W-L (2021) Cefoperazone/sulbactam: New composites against multiresistant gram negative bacteria? Infect Genet Evol 88:1-9

Kucukbay Z, Savan EK, Celen S, AZAZ AD, Arabaci T (2014) Chemical composition of the essential oils of three Thymus taxa from Turkey with antimicrobial and antioxidant activities. Rec Nat Prod 8:110-120

Kuhn D, Ziem R, Scheibel T, Buhl B, Vettorello G, Pacheco LA, Heidrich D, Kauffmann C, Freitas EM, Ethur EM, Hoehne L (2019) Antibiofilm activity of the essential oil of Campomanesia aurea $\mathrm{O}$. Berg against microorganisms causing food borne diseases. LWT - Food Sci Technol 108:247-252

Limaverde PW, Campina FF, Cunha FAB, Crispim FD, Figueredo FG, Lima LF, Oliveira-Tintino CDM, Matos YMLS, Morais-Braga MFB, Menezes IRA, Balbino VQ, Coutinho HDM, Siqueira-Júnior JP, Almeida JRGS, Tintino SR (2017) Inhibition of the TetK effux pump by the essential oil of Chenopodium ambrosioides $\mathrm{L}$. and $\alpha$-terpinene against Staphylococcus aureus IS-58. Food Chem Toxicol 109:957-961

Luz IS, Melo ANF, Bezerra TKA, Madruga MS, Magnani M, Souza EL (2014) Sublethal amounts of Origaunm vulgare L. essential oil and carvacrol cause injury and changes in membrane fatty acid of Salmonella Typhimurium cultivated in a meat broth. Foodborne Pathog Dis 11:357-361 
Matias EFF, Santos KKA, Almeida TS, Costa JGM, Coutinho HDM (2011) Phytochemical screening and modulation of antibiotic activity by Ocimum gratissimum L. Biomed Prevent Nutrition 1:57-60

MOHAMMADHOSSEINI M. (2017) The ethnobotanical, phytochemical and pharmacological properties and medicinal applications of essential oils and extracts of different Ziziphora species (Review). Ind Crops Prod 105:164-192

Nunes ASF, Lima IS, Osório LR, Abreu APL, Santos BHC, Lima EO, Silva Filho EC, Ferreira JHL, Barreto HM (2014) Efeito do óleo essencial de Ocimum basilicum L. na resistência aos aminoglicosídeos em Staphylococcus aureus. Boletim Informativo Geum $5: 31-37$

Obeidat M, Shatnawi M, Al-mazra'awi MS, Al-Zu`bi E, Al-Dmoor H, Al-Qudah MMA, El-Qudah J, Otri I (2012) Antimicrobial activity of crude extracts of some plant leaves. Research J Microbiol 7:59-67

Pessoa SM, Zárate NAH, Vieira MC, Cardoso CAL, Poppi NR, Formagio ASN, Silva LR (2015) Total biomass and essential oil composition of Ocimum gratissimum L. in response to broiler litter and phosphorus. Rev bras plantas med 17:18-25

Requena R, Vargas M, Chiralt A (2019) Study of the potential synergistic antibacterial activity of essential oil components using the thiazolyl blue tetrazolium bromide (MTT) assay. LWT - Lebensm Wiss Technol 101:183-190

Al-Rimawi F, Jaradat N, Qneibi M, Hawash M, Emwas N (2020) Free radicals and enzymes inhibitory potentials of the traditional medicinal plant Echium angustifolium. European J Integr Med 38:1-6

Santiesteban-López A, Palou E, López-Malo A (2007) Susceptibility of food-borne bacteria to binary combinations of antimicrobials at selected $\mathrm{a}(\mathrm{w})$ and $\mathrm{ph}$. J Appl Microbiol 102:486-497

Sharma V, Joshi A, Dubey BK (2011) Comparative pharmacognostical and phytochemical evaluation (leaf) of different species of Ocimum. Inter $\mathrm{J}$ Phytopharmacology 1:43-49

Swamy MK, Akhtar MS, Sinniah UR (2020) Antimicrobial properties of plant essential oils against human pathogens and their mode of action: an updated review. Evidencebased Complem Altern Med 2016:1-7

Xie Y, Wang K, Huang Q, Lei C (2014) Evaluation toxicity of monoterpenes to subterranean termite, Reticulitermes chinensis Snyder. Ind Crops Prod 53:163-166

Zemolin APP, Cruz LC, Paula MT, Pereira BK, Albuquerque MP, Victoria FC, Pereira AB, Posser T, Franco JL (2014) Toxicity induced by Prasiola crispa to fruit fly Drosophila melanogaster and cockroach Nauphoeta cinerea: evidence for bioinsecticide action. J Toxicol Environ Health A 77:115-124 
620 Zhang X, Guo Y, Guo L, Jiang H, Ji Q (2018) In vitro evaluation of antioxidant and 621 antimicrobial activities of Melaleuca alternifolia essential oil. BioMed Research Inter $622 \quad 2018: 1-8$

623

624

625

626

627

628

629

630
Zhang Z, Yang T, Zhang Y, Wang L, Xie Y (2016) Fumigant toxicity of monoterpenes against fruitfly, Drosophila melanogaster. Ind Crops Prod 81:147-151

Al Zuhairi JJMJ, Kashi FJ, Rahimi-Moghaddam A, Yazdani M (2020) Antioxidant, cytotoxic and antibacterial activity of Rosmarinus officinalis L. essential oil against bacteria isolated from urinary tract infection. European J Integr Med 38:1-8 
631

632

633

634

635

636

637

638

639

\section{FIGURES}

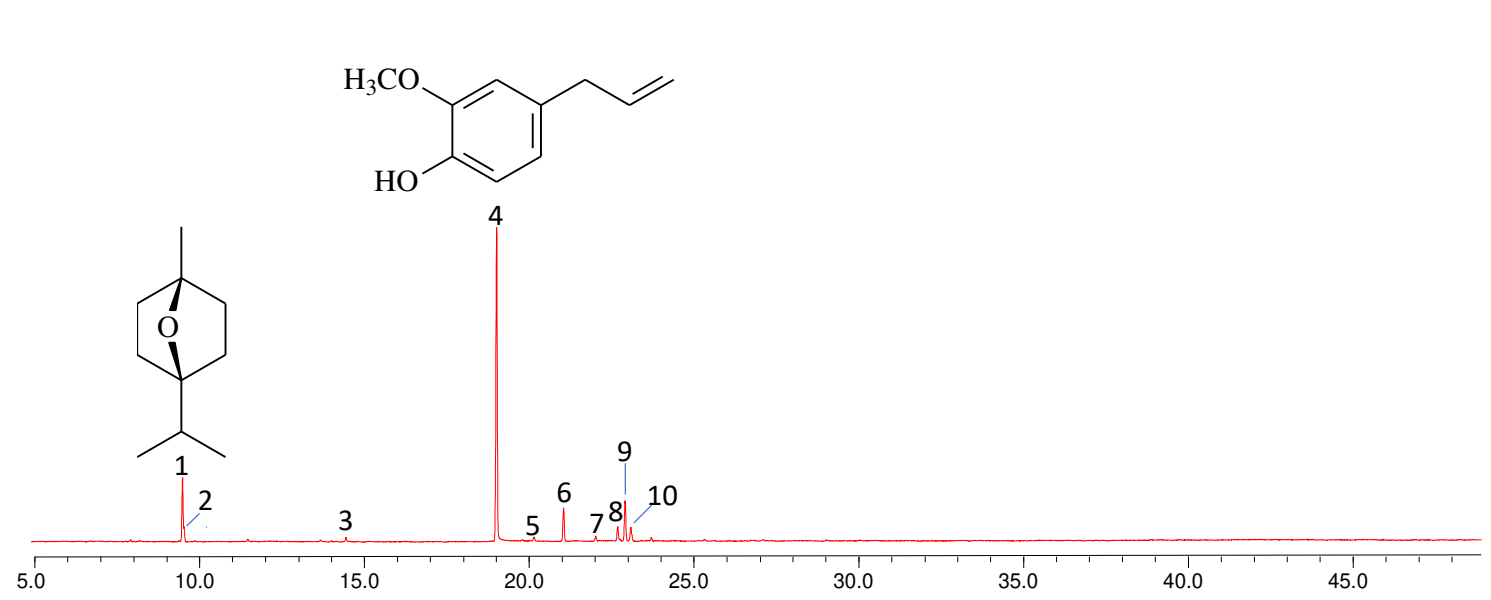

Fig. 1 Chromatogram CG-MS of the essential oil of Ocimum gratissimum L. $1=1$,8-cineole-eucalytol; 2 = Cis-ocimene; 3 = 1-alpha-terpineol; 4 = Eugenol; $5=$ Beta-element; $6=$ Trans-caryophyllene; 7 = Alphahumulene; $8=$ Germacrene-D; $9=$ Beta-selinene; $10=$ Alpha-selinene 
(a)

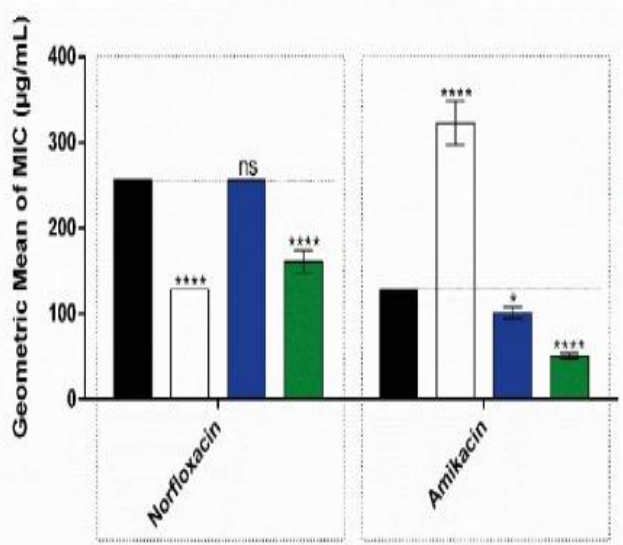

(c)

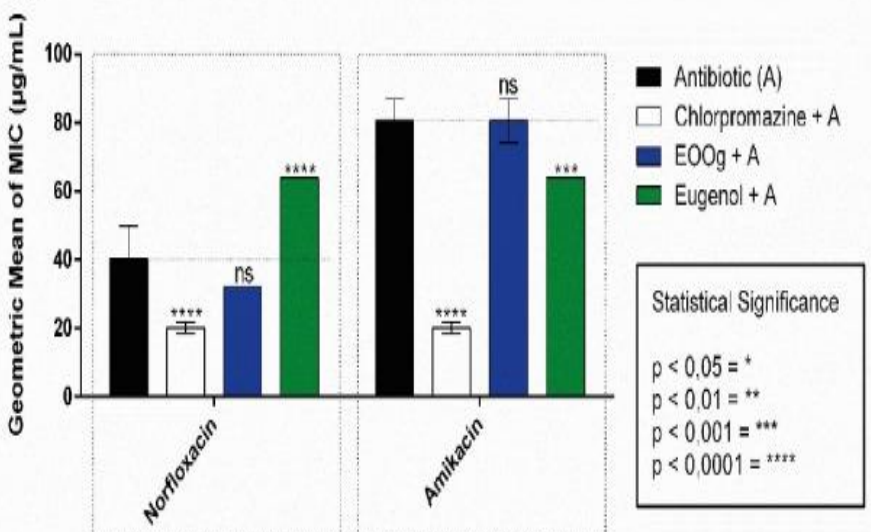

(e) Staphylococcus aureus

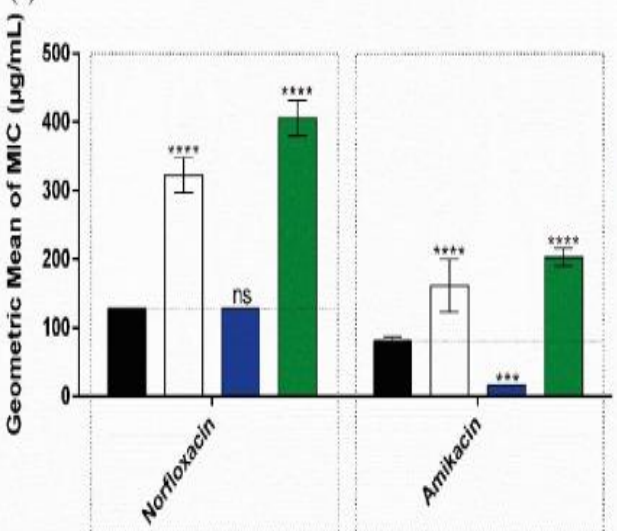

- Antibiotic (A)

$\square$ Chlorpromazine $+A$

EOOg+A

- Eugenol $+A$

Statistical Significance

$p<0.05=*$

$p<0,01=*$

$p<0.001=*+*$

$p<0.0001=* *+\cdots$ (b)

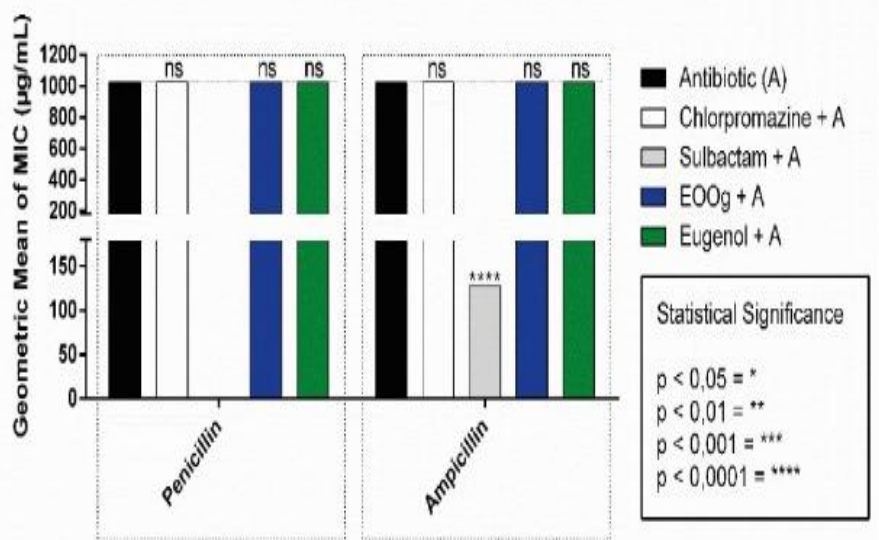

(d)
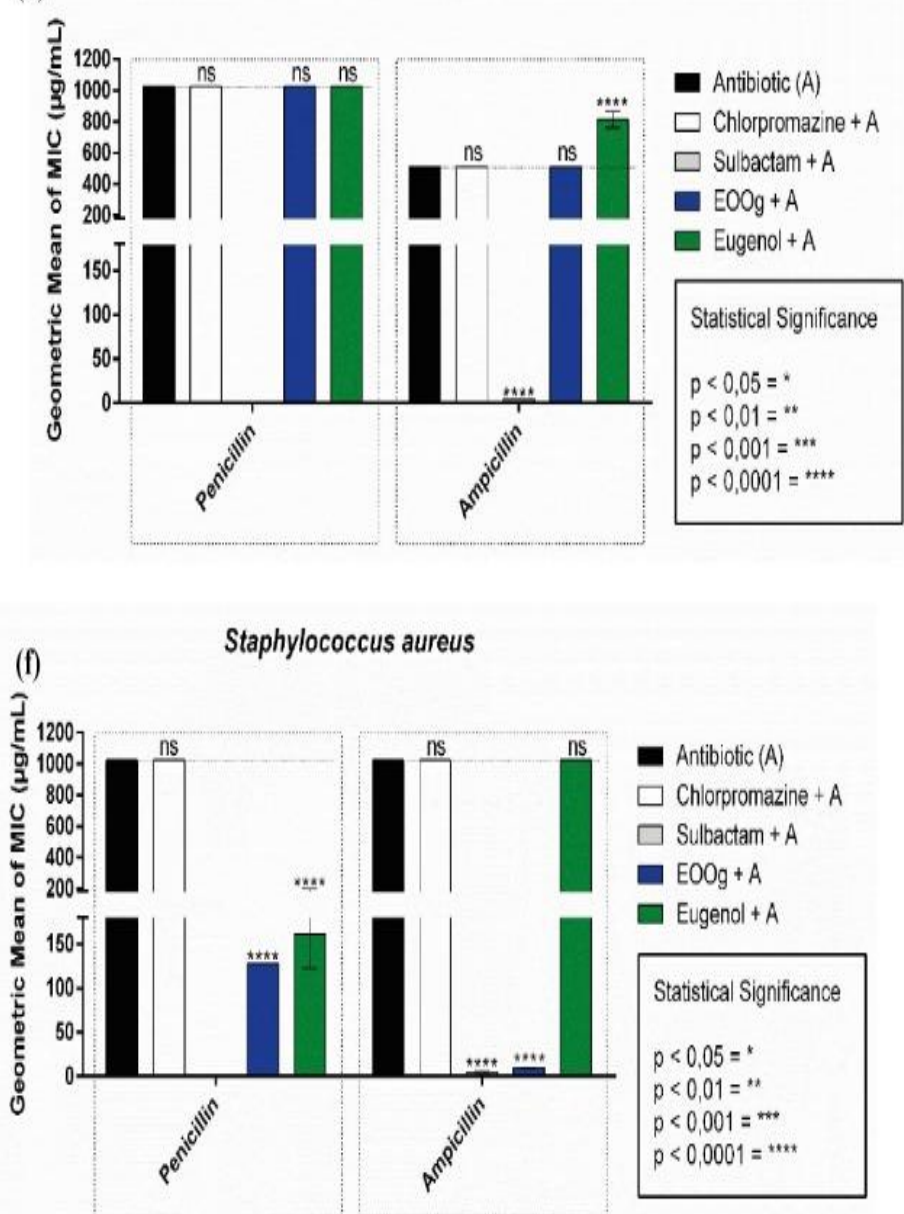

641 Fig. 2 Evaluation of antibiotics modifying activity (Amikacin, Ampicillin, Norfloxacin and Penicillin) by

642 EUG and EOOg against bacterial strains (Escherichia coli 06, Pseudomonas aeruginosa 24 and

643 Staphylococcus aureus 10)

644 
(a)

Mortality

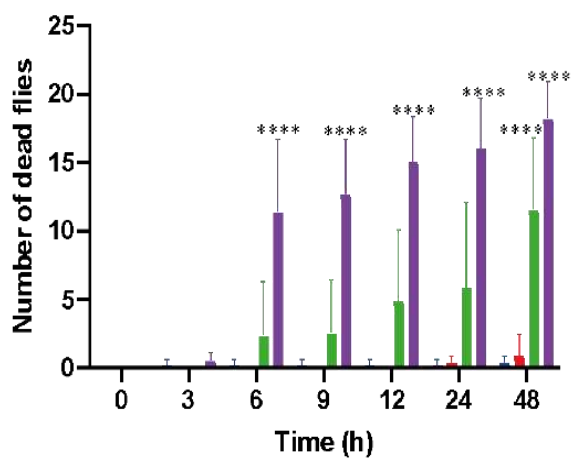

Essential oil (b)

$$
\begin{aligned}
& \text { Control } \\
& 1 \mu \mathrm{L} / \mathrm{mL} \\
& 5 \mu \mathrm{L} / \mathrm{mL} \\
& 10 \mu \mathrm{L} / \mathrm{mL} \\
& * * * *=p<0.0001
\end{aligned}
$$

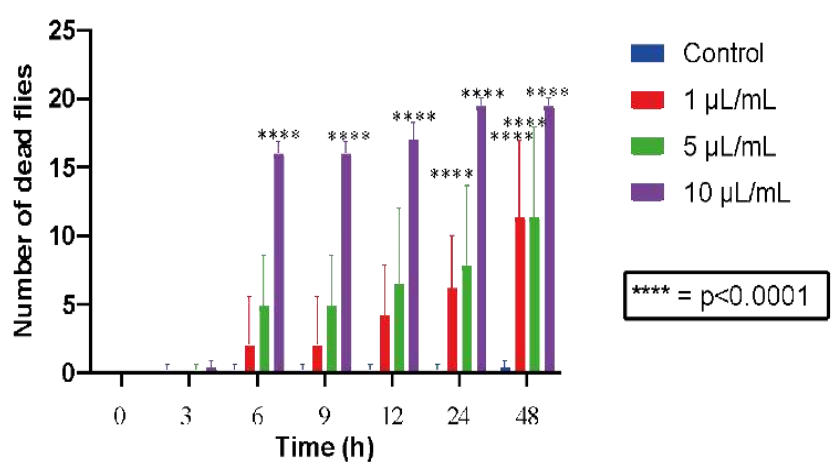

Eugenol

647 Fig. 3 Effect of Essential oil of Ocimum gratissimum L. (a) and Eugenol (b) on the mortality test of 648 Drosophila melanogaster at different concentrations and time

649 
(a) Negative geotaxis behavior

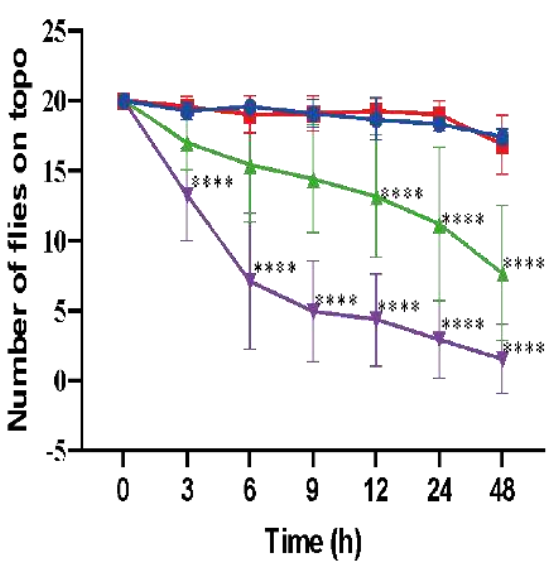

Essential oil (b) Negative geotaxis behavior

$\rightarrow$ Control

$\rightarrow+1 \mu \mathrm{L} / \mathrm{mL}$

$+5 \mu \mathrm{L} / \mathrm{mL}$

$\mp 10 \mu \mathrm{L} / \mathrm{mL}$

$* * * *=p<0.0001$

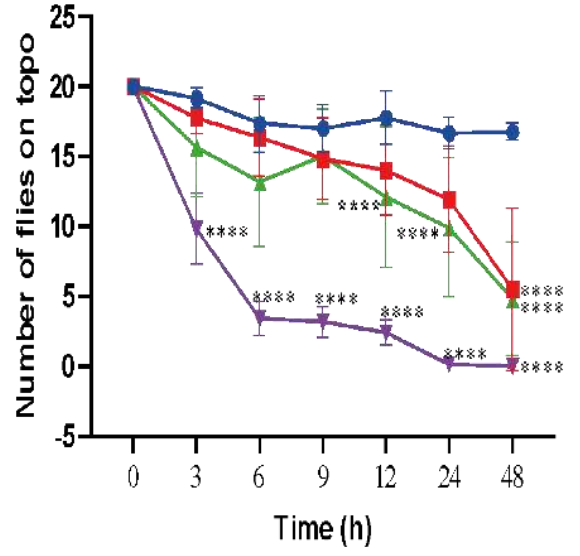

- Control

$+1 \mu \mathrm{L} / \mathrm{mL}$

$+5 \mu \mathrm{L} / \mathrm{mL}$

$+10 \mu \mathrm{L} / \mathrm{mL}$

$* * * *=p<0.0001$

650

651 Fig. 4 Effect of the Essential oil of Ocimum gratissimum L. (a) and Eugenol (b) on the negative geotaxis

652 behavior of Drosophila melanogaster in different concentrations and time

653

654

655

656 